Article

\title{
Carbon Footprint of Inbound Tourism to Iceland: A Consumption-Based Life-Cycle Assessment including Direct and Indirect Emissions
}

\author{
Hannah Sharp, Josefine Grundius and Jukka Heinonen * \\ Faculty of Civil and Environmental Engineering, University of Iceland, Hjardarhagi 2-6, 107 Reykjavík, Iceland; \\ hks16@hi.is (H.S.); ajg13@hi.is (J.G.) \\ * Correspondence: heinonen@hi.is; Tel.: +354-823-0064 \\ Academic Editor: Marc A. Rosen \\ Received: 25 June 2016; Accepted: 1 November 2016; Published: 8 November 2016
}

\begin{abstract}
The greenhouse gas (GHG) emissions caused by tourism have been studied from several perspectives, but few studies exist that include all direct and indirect emissions, particularly those from aviation. In this study, an input/output-based hybrid life-cycle assessment (LCA) method is developed to assess the consumption-based carbon footprint of the average tourist including direct and indirect emissions. The total inbound tourism-related GHG emissions are also calculated within a certain region. As a demonstration of the method, the full carbon footprint of an average tourist is assessed as well as the total GHG emissions induced by tourism to Iceland over the period of 2010-2015, with the presented approach applicable in other contexts as well. Iceland provides an interesting case due to three features: (1) the tourism sector in Iceland is the fastest-growing industry in the country with an annual growth rate of over $20 \%$ over the past five years; (2) almost all tourists arrive by air; and (3) the country has an almost emissions-free energy industry and an import-dominated economy, which emphasise the role of the indirect emissions. According to the assessment, the carbon footprint for the average tourist is 1.35 tons of $\mathrm{CO}_{2}$-eq, but ranges from 1.1 to 3.2 tons of $\mathrm{CO}_{2}$-eq depending on the distance travelled by air. Furthermore, this footprint is increasing due to the rise in average flight distances travelled to reach the country. The total GHG emissions caused by tourism in Iceland have tripled from approximately 600,000 tons of $\mathrm{CO}_{2}$-eq in 2010 to $1,800,000$ tons in 2015 . Aviation accounts for $50 \%-82 \%$ of this impact (depending on the flight distance) underlining the importance of air travel, especially as tourism-related aviation is forecasted to grow significantly in the near future. From a method perspective, the carbon footprinting application presented in the study would seem to provide an efficient way to study both the direct and indirect emissions and to provide new insights and information to enable the development of appropriate GHG mitigation policies in the tourism sector.
\end{abstract}

Keywords: carbon footprint; greenhouse gas; life-cycle assessment; input-output; tourism; transport; aviation

\section{Introduction}

Climate change is now widely recognised as the major environmental problem facing the globe [1] The Intergovernmental Panel on Climate Change (IPCC) [2] has reported that most of the observed warming is likely due to the increase in concentration of greenhouse gas (GHG) emissions in the atmosphere, with this conclusion having been widely accepted. Almost all human activities are involved in the emission of greenhouse gases, directly or indirectly, through combustion of fossil fuels or the disruption or removal of carbon sinks such as forests, leading to the observed increase in the GHG concentration in the atmosphere [3]. The tourism industry is a significant source of these 
emissions with its contribution expected to grow considerably in the future as the sector expands. Currently, the tourism industry accounts for more than $30 \%$ of global exports of services, $6 \%$ of total exports and $9 \%$ of global GDP [4].

Many of the activities undertaken by the tourism sector are energy-intensive, including transport, delivering amenities and providing accommodation and other facilities for tourist needs. In many cases, this means that such tourist destinations might have greater emissions compared to other similar-sized, non-tourism-based communities [5]. Tourism also drives the construction of new infrastructure and buildings, such as hotels, further adding to the emissions intensity of the sector. Most destinations also use considerable amounts of energy for importing food and other material goods and for disposing of waste [6,7]. Aviation has also been shown to contribute significantly to overall emissions from the sector (e.g., [5,7-12]) and is often the major source of tourism-related energy use [5]. This is particularly apparent for those destinations that are isolated or island-based, where tourists overwhelmingly arrive by air $[5,8]$. For example, in the Caribbean islands, Gössling [13] reported that the share of emissions related to air travel was between $44 \%$ and $71 \%$ of total emissions across the region. Still, despite the increased attention being paid to tourism-induced aviation and the need to mitigate GHG emissions, significant gaps in the research exist [14]. The issue is further complicated by the fact that aviation emissions are accounted for differently across the literature with no agreement on how to best deal with them [12]. In spite of this, there is widespread consensus that this source of emissions should be included in national accounting frameworks to enable better understanding and encourage mitigation policies [12].

On a global scale, the UN World Tourism Organisation (UNWTO) reported that in 2005 tourism contributed approximately $5 \%$ of $\mathrm{CO}_{2}$ emissions worldwide. These emissions were predominantly from the transport sector, which generated $75 \%$ of the total emissions for the tourism industry [15]. Projected forward under business-as-usual scenarios, it was estimated that the growth of the sector could result in an increase in $\mathrm{CO}_{2}$ emissions of $152 \%$ by 2035 , even when improvements in efficiency are accounted for [15]. Consequently, many studies have been undertaken to give some idea of the scale of impact that tourism has on emissions. Dwyer et al. [5] found that in Australia, the tourism sector contributes between $3.9 \%$ and $5.3 \%$ of total industry GHG emissions in Australia, making it the fifth highest emissions sector in the nation. A similar result was found for Switzerland [16], with the study finding that the tourism sector was four times more GHG intensive than the Swiss economy on average, accounting for $5.2 \%$ of total national emissions. In a summary of national tourism sector emissions based on 27 studies across 22 countries [13], tourism was found to be equivalent to between $4 \%$ and $150 \%$ of total national emissions, with the highest emissions observed in small island developing states such as Turks and Caicos. However, Gössling [13] further concluded that even in developed economies where tourism is not the dominant economic sector, the results confirm the high energy intensity of the industry in general. Analysis by Scott et al. [17] shows that if the current high-growth trends in emissions continue, tourism is likely to become a major source of GHGs for the globe.

Alongside the contributions tourism makes to global emissions, various studies have looked at the possible consequences of continued climate change on the tourism industry (e.g., $[5,9,14])$. Tourism around the world is likely to be affected both directly and indirectly from shifts in the global climate in many different ways. For example, climate change has the capacity to significantly alter the appeal of certain tourism destination through affecting the climate directly, increasing adverse weather events or altering the natural environment [15]. Flow-on effects from emissions mitigation policies, changing social conditions and economic issues are also predicted to indirectly impact the sector [15]. A study by UNWTO [18] identified climate change vulnerability hotspots for the sector globally, summarising the anticipated direct and indirect impacts on different regions. For example, the report suggested that islands in the Caribbean are likely to be subjected to direct impacts from increased extreme weather events, sea level rise and water scarcity with indirect effects also felt from political destabilisation and increased travel costs. In some countries, such impacts are already being felt, with Tobago 
amongst numerous countries reporting regular water shortages for accommodation providers and tour operators due to increasing droughts and more extreme summer temperatures [18]. The report by UNWTO [18] predicted similar impacts for the Mediterranean, which is likely to experience issues including water scarcity, biodiversity loss and increased disease outbreaks. Such studies have all increased awareness of the impacts of tourism-related energy consumption and emissions around the world and the ways in which climate change may impact destinations [5]. This has led to an increased demand to quantify the impact of such energy-related activities and develop appropriate, effective management strategies [5].

However, despite many experts highlighting the increasing importance of understanding the role of tourism in emissions, much of the current analysis and policy responses continue to ignore the sector $[9,13,19]$. As the impacts of climate change and the characteristics of the tourism sector differ substantially between destinations, effective tourism-specific mitigation policies cannot be designed without thorough assessment of national tourism sectors [13,20], of which comprehensive studies and assessments are lacking [20]. In addition, because tourism is often not seen as a true economic sector in its own right, it is often excluded from the System of National Accounts, meaning countries most often do not have comprehensive statistics relating to its energy consumption or emissions [5]. This is particularly problematic when it comes to capturing the significant emissions from international air travel due to the difficulty in properly allocating these emissions [21]. At present, international aviation is excluded from Kyoto reporting requirements, which only covers domestic transport [22]. That the field of environmental assessments of tourism is still in the early stages of development is widely acknowledged in the literature (e.g., $[9,20,23,24]$ ), particularly in relation to climate change, where accurate quantification of emissions is critical [8]. The result of this is a limited understanding of the role of tourism in global emissions and climate change, preventing the design and adoption of effective mitigation approaches [19].

Within the existing literature on this topic, there has been a wide range of approaches adopted for assessment of the sector. A review by Filimonau et al. [19] found that many studies focussed solely on identifying environmental impacts related to tourism with no analysis of the consequences, with others examining perceptions or attitudes towards the sector's impact held by tourists or tourism-related businesses. Of those that have attempted to quantify the carbon impact of tourism for specific destinations, both bottom-up and top-down methodologies have been used including GHG conversion factors, environmental impact assessments and ecological footprint analyses often using Tourism Satellite Accounts [13]. Examples of these studies include an assessment by Patterson and McDonald [9], which quantified all environmental impacts arising from tourist activities in New Zealand, with the energy use of tourism in that country also examined by Becken et al. [25]. To date, there have been five emissions-related assessments for the country, each adopting different emissions allocations scenarios [13]. The GHG emissions related to tourism energy use in Whistler, Canada were also quantified using a bottom-up approach [26]; however, induced effects were excluded. Another study [27] assessed the waste and GHG emissions due to tourism in Wales and a recent study in 2010 aimed to quantify the GHG impacts from tourism solely in Australia [5]. This study used both a "production" and "expenditure" (or consumer) approach based on the national Tourism Satellite Account to calculate the emissions for the year 2003/2004. Gössling [28] investigated the use of the ecological footprinting technique in assessing environmental impacts of tourism on the Seychelles; however, quantifying GHG emissions was not the primary focus. In Iceland, Björnsson [29] studied the carbon emissions generated by foreign tourists with a bottom-up approach using three representative tourist types. However, this analysis was limited to the direct emissions stemming from only three tourism-related sectors-transport, accommodation and activities. In a summary article, Gössling [13] identified 27 emissions-related studies in the literature covering 22 national tourism sectors.

While acknowledging these and other existing important contributions to the academic literature, it has been suggested that additional comprehensive studies are needed that account for the full scope of emissions related to tourism including both the direct and indirect impacts $[13,20]$. While some 
studies have included an analysis of both of these impacts (e.g., [5,11,12,27]), many assessments have adopted limited system boundaries (e.g., $[7,16,27])$ that exclude indirect emissions, and important tourism sub-sectors or impacts, often due to complexities in defining the extents of tourism in the economy of which there remains no single definition [13]. In fact, in the aforementioned review by Gössling [13], none of the 27 studies adopted comprehensive system boundaries in the assessment, meaning that the results are likely to only be indicative of the true impact of tourism.

While there are valuable studies on the GHGs from tourism with wide assessment boundaries in the literature, they often include only direct impacts from tourism activities, with indirect impacts (scope 3) commonly excluded (e.g., [7,16,27]), which leaves room for further contributions. Direct impacts are generated directly from tourist activities, while indirect impacts result from intermediate inputs due to all other emissions-causing activity related to the industry [30]. These emissions are largely spread around the world embedded in international trade. In spite of being largely absent in tourism-related literature, the significance of indirect emissions has been widely reported and quantified in many other sectors, from consumer carbon footprints [31] to general urban sustainability [32], service industries [33], engineering and construction (e.g., [34,35]), with many studies suggesting that the contribution of indirect emissions can be potentially much higher than direct emissions [36,37]. They are also particularly important for services which form an important part of tourists' consumption. Exclusion of indirect emissions from services also means that the majority of emissions are not captured, as the impact from the final point of delivery of a service is often only minor compared to that from the required material inputs [33]. While not a comprehensive assessment, an analysis of the indirect emissions associated with different tourism-related activities by Filimonau et al. [19] suggested that the indirect carbon footprint for hotels and tourism transport could be as high as $20 \%$ and $65 \%$ of the respective totals. The scale of the importance of indirect emissions has been further echoed in other studies, as for example by $[12,38,39]$. Furthermore, there are suggestions that the share of carbon impacts due to indirect emissions is likely to increase in the future, due to the comparative simplicity in reducing direct emissions, making it even more critical to include this issue in assessments [40]. In recognition of the importance of including the full range of emissions related to national tourism, a number of methodologies have been proposed for the calculation [41] including the life-cycle assessment (LCA) approach (e.g., [42]). LCA enables the full scope of emissions embedded in all related goods and services to be accounted for and, while it has so far had limited application in the tourism sector (e.g., $[19,20,23,43])$, it offers an opportunity to improve the quality and accuracy of environmental assessments [44]. Especially applicable to national scale emission studies, the LCA methodology is able to give broader information on the impact of the sector, which can be particularly important for effective policy-making [43].

In light of this, the aim of this study is to take a step towards an improved understanding of the overall GHG emissions induced by tourism directly and indirectly. An input-output (IO)-based hybrid LCA method is presented to study the full scope of emissions caused by tourism. This approach has been identified as a viable solution to the problem of truncation and boundary selection [19,45]. As a demonstration of the method, the full carbon footprint of an average foreign tourist is assessed with a consumption-based approach that allocates the emissions to the consumers of goods and services [41,46], and then the overall GHGs induced by inbound tourism to Iceland over the period 2010-2015 are estimated. Iceland provides an interesting case due to three features. First, the tourism sector in Iceland is the fastest-growing industry in the country with an annual growth rate exceeding $30 \%$ in the most recent years [47]. Second, as Iceland is a remotely located island, almost all tourists arrive by air, which is a very GHG-intensive travel mode. Third, the country is unique in terms of GHG emissions due to its almost emissions-free energy industry and import-dominated economy, which emphasise the role of the indirect emissions. The presented hybrid LCA approach is applicable in other contexts as well.

According to the study, the per capita emissions caused by the average tourist visiting Iceland are approximately 1.35 tons $\mathrm{CO}_{2}$-eq, but quickly increase up to over 3 tons as the flight distance 
rises. Overall, this study finds that tourism currently causes GHG emissions of close to 2,000,000 tons annually in Iceland. Annual emissions are rapidly growing due to the increasing number of tourist visits as well as a rise in the average flight distance, with the most significant growth observed in the number of tourists arriving from Asia and North America.

The paper is structured as follows: the next section outlines the research method applied to calculate the carbon footprint of an average tourist, followed by a section outlining the research design and data sources utilised. The fourth section presents the results of the study. Section five provides a discussion of the results comparing the carbon footprint with that calculated in the previous study on Iceland as well placing the results in a global tourism context.

\section{Method}

The method utilised in this study is LCA-based carbon footprinting. The LCA approach is in accordance with ISO 14044 [48], with the guidelines of Wiedmann and Minx [41] and Minx et al. [46] followed for consumption-based carbon footprinting.

LCA is a method for analysing the impacts of a good, service or system over its life cycle including all the utilised energy and material inputs. This means that both the direct and the indirect emissions are captured [49-51]. There are two main approaches to LCA; Process LCA and Input-Output (IO) LCA, with hybrid LCAs combining aspects of both [36]. IO LCAs are commonly called environmentally extended IO LCAs (EE IO LCA) or economic IO LCAs (EIO LCA), but in this study will be referred to as IO LCA. This study employs an IO LCA-based hybrid model, which aims to take advantage of the strengths of the two methods. More particularly, the employed method is called tiered hybrid LCA (e.g., [52]), an approach that is further discussed below.

IO LCA is an efficient method for capturing both the direct and indirect emissions caused by the studied system [45]. IO LCA is a top-down method that approximates environmental impact through the utilisation of "sectorial monetary transaction matrices" [53], in other words, by calculating the environmental output per monetary expenditure in the sector. By describing the inputs that a given sector of an economy requires from all other sectors to produce a unit of output [54], the IO LCA method can model the complete and complex interdependencies that exist between economic sectors [52]. Using the assumption that an increase in the output of goods or services from one sector requires a proportional increase in inputs from others, the economic output for each stage of the life cycle can be determined [54]. This information is expressed as a normalised matrix of technical coefficients. To calculate the total environmental impact, this economic matrix is simply inverted and multiplied by a corresponding matrix of impact intensities (environmental impact per monetary unit of output) $[52,54]$. This calculation results in the determination of the total consumption-based environmental impact across the economy for producing a particular product or service. A full description of the IO LCA derivation and calculation methodology can be found in [55-57].

The IO LCA method inherently includes the complete production and delivery chains associated with producing a good or service and, therefore, the direct and indirect emissions. It is very efficient in analyses intending to include the indirect emissions, particularly those of services, whose impact can easily be significantly underestimated $[33,36,37]$. In general, IO LCAs and IO-based hybrid LCAs are more comprehensive than the more traditional process LCAs, which suffer from some level of truncation error $[37,52]$. Another important benefit of this approach is that the data required for the assessment is often regularly collected as part of national statistics in many countries [52]. Through the combined effects of using publically available data and consistent boundaries of analysis, the IO LCA enables a relatively quick and inexpensive estimate to be produced of the environmental impacts of a certain process across an economy [54]. While the environmental impacts included in a particular IO model can be varied to include almost anything, the significant data requirements and workload of producing the IO tables mean they are commonly limited to a number of key impact categories. Typically, the number of impacts is fewer than that available in process LCA databases. 
The input-output tables utilised for the LCA assessment combine various products, production technologies and services into aggregated commodity sectors [52], disguising the heterogeneous resources, processes and environmental impacts associated with each. As such, IO LCA is generally more suited to assessing typical, aggregate products that can be well represented by the relevant commodity sector [54]. Furthermore national input-output data assumes that for a single region, all production methods are the same, including those for imported commodities, and that there is no impact from ignoring price heterogeneity that can distort flows between industries [52]. Another limitation of IO LCA is the assumed linear relationship between sector outputs and environmental burdens [58]. Data age and incomplete sectorial statistics further compound the issue, resulting in a generalised, approximate assessment of the environmental impact of a production decision [52]. In addition, this method generally does not take into account potential end-use GHGs or land use change impacts.

In adopting the tiered hybrid LCA approach, some of these weaknesses can be reduced. In a tiered hybrid LCA model, certain phases in the production and delivery chain (known as tiers) are replaced with specific process data [52]. Higher-order upstream tiers, representing indirect emissions, are still assessed with IO analysis to maintain the comprehensiveness of the assessment. For example, in the energy sector, the production phase (the first tier) can be replaced with local up-to-date data instead of using the model average and potentially old data. In general, the tiered hybrid approach reduces the level of uncertainty in the calculation related especially to: (1) data age, as more up-to-date data can be used; (2) average production technology assumption, if production technology specific to the assessment object is used; and (3) the aggregation error, when data specific to the assessment object is used in place of the industry sector average as is typical in IO models; (4) by adding use-related emissions to the assessment for sectors including only cradle-to-gate emissions (e.g., fuel combustion from driving). It has been suggested that hybrid LCAs can provide combination of comprehensiveness and accurateness not achievable by either one of the LCA approaches alone [52].

In consumption-based carbon footprint assessments, the GHGs are allocated to the users of the goods and services (e.g., [32,41,46]. IO and hybrid LCAs have a relatively established position in consumer carbon footprint assessments [32,41,46], but the method has not been applied widely for assessing the carbon footprints of tourists, even though it can be successfully utilised. The same strength of assessment comprehensiveness, which makes the method widely accepted in the field of consumer carbon footprinting [32], is an important attribute in any consumption-based GHG assessments.

\section{Research Design}

The hybrid LCA model was applied to estimate the carbon footprint of the average foreign tourist in Iceland. This figure was then used to calculate the total approximate GHG impact from tourism for the country during the period 2010-2015. For this study, the scope of the assessment and functional unit are first defined as discussed in Section 3.1 with the relevant data used in the assessment described in Section 3.2. Further information on the application of the hybrid LCA model to calculate the carbon footprint and total GHG impact is then presented in Section 3.3.

\subsection{Assessment Scope and Boundaries}

In the first stage of the assessment, the calculation of the carbon footprint was undertaken based on the activities of an average tourist in Iceland. The definition of a "tourist" was adopted from the following description from the United Nations World Tourism Organisation [59]:

A visitor is a traveller taking a trip to a main destination outside his/her usual environment, for less than a year, for any main purpose [... ] other than to be employed by a resident entity in the country or place visited. A visitor (domestic, inbound or outbound) is classified as a tourist [ ... ] if his/her trip includes an overnight stay. 
Extending this definition to the case of Iceland, data from the Icelandic Tourism Board and Statistics Iceland was utilised to define the "average tourist" for whom a carbon footprint could be calculated. In this study, the "average tourist" was defined as a visitor staying in Iceland for an average duration of 6-10 nights (average nights spent in winter and summer respectively) $[60,61]$ and spending on average 192,440 ISK per person [62]. In the second stage, the calculated carbon footprint was used to examine the change in total GHG emissions for Iceland over the period 2010 to 2015. During this time, tourism to Iceland has seen a rapid increase [63]. For this analysis, the assumption was made that the tourist activities and consumption patterns have not changed over the five-year period, with the uncertainties related to this assumption discussed in Section 5.

As shown in Table 1, the boundary of this study has been defined based on an aggregation of the expenditure categories that make up the Icelandic tourism sector, discussed further in Section 3.2. Air travel has also been included in the scope of the carbon footprint calculation due to the scale of the impact of this form of transport. As Iceland is an island with the vast majority of tourists arriving by air, this sector is likely to have a significant impact on the results. Because of the inherent nature of the IO LCA, this boundary definition naturally extends to include the complete production and delivery chains behind each product and service [9]. Unlike the process LCA method which will contain some degree of truncation error depending on how far up the supply chain inputs are tracked [37], the IO approach is a cradle-to-gate model which implicitly tracks the inputs required by any sector of the economy from all other sectors to produce some output $[9,54]$. The methodology behind the input-output LCA is discussed in Section 2. The functional unit of the study is defined as one average tourist with the results presented as kilograms of $\mathrm{CO}_{2}$ equivalent per tourist, later referred to as $\mathrm{kg} \mathrm{CO}_{2}$-eq/tourist.

Table 1. Boundaries of the assessment.

\begin{tabular}{lll}
\hline \multicolumn{1}{c}{ Included } & \multicolumn{1}{c}{ Excluded } \\
\hline - $\quad$ Local transport & \\
- $\quad$ Accommodation and restaurant services & $\begin{array}{l}\text { Tourism consumption related to transport to/from the } \\
\text { airport or harbour in the tourist's country of origin }\end{array}$ \\
- $\quad$ Recreation and leisure services & \\
\hline $\begin{array}{l}\text { Inbound tourism consumption related to } \\
\text { airfares to reach Iceland }\end{array}$ & Domestic or outbound tourism activities \\
\hline
\end{tabular}

Through utilising an IO LCA and drawing on tourism expenditure data, the carbon footprint calculation is able to capture not only the direct emissions produced by the tourism sector but also the indirect emissions associated with the secondary services and products that support and feed into the industry. Direct emissions are also known as scope 1 emissions with indirect emissions captured under scopes 2 and 3 (e.g., [30]). Scope 1 includes mainly fuel combustion when considering touristic activities, but in general also process emissions and fugitive emissions. The category of scope 2 includes all emissions connected to consumption of energy e.g., for heating, lighting and appliances, with scope 3 encompassing emissions from the manufacture and delivery of purchased goods and services [64], in the tourist context meaning the majority of the emissions related to all the consumption activities, e.g., food production, production of souvenirs, running service facilities, etc. Few studies so far exist that capture scope 3 for all tourist activities.

\subsection{Data}

The characteristics and sources of the data used in the carbon footprint analysis are described below. The study primarily drew on input data relating to the number of tourists that visited Iceland in the target year and their expenditure whilst in the country. The most recent data available was for 
2013, meaning this year was taken as the target year for the study. In order to capture the emissions generated by tourists travelling to Iceland, additional data was obtained relating to their countries of origin as well as the aircraft most commonly used in passenger transport.

\subsubsection{Touristic Visits}

Data for touristic visits in Iceland was obtained from Icelandic Tourist Board [47] for visitors having arrived by plane in 2010-2015. The dataset includes the number of visits from the 17 most common departure countries, covering approximately $85 \%$ of the overall visitors, and a category "other" covering the remaining 15\%. Of these 17 countries, 13 are European (Denmark, Finland, France, Germany, Italy, Netherlands, Norway, Poland, Russia, Spain, Sweden, Switzerland and United Kingdom), two are located in North America (Canada and USA) with two from Asia (China and Japan). Russia was categorised as a European country due to the majority of the visitors presumably coming from the European part. No data was available for the remaining $15 \%$, but the treatment in the assessments is explained in Section 3.2.3.

According to this data, the number of touristic visits to Iceland increased from slightly below 500,000 annual visits in 2010 to 1.26 million visits in 2015. In 2013, the base year of this study, approximately 780,000 visits were made. UK and USA are the most important departure countries and account for almost $20 \%$ of total visits to Iceland. Overall, all regions show increasing visitor numbers but the relative share arriving from Europe has been falling, decreasing from $70 \%$ in 2010 to roughly $50 \%$ in 2015, whereas the share from North America and Asia is increasing. Table 2 presents the origins of visitors according to continent, with the category "other" depicted as Unknown (thousands of visitors).

Table 2. Visitors according to the departure continent in 2010-2015 (thousands).

\begin{tabular}{ccccc}
\hline & Europe & North America & Asia & Unknown \\
\hline 2015 & 617 & 258 & 59 & 175 \\
2014 & 589 & 191 & 47 & 142 \\
2013 & 493 & 144 & 37 & 108 \\
2012 & 421 & 114 & 29 & 83 \\
2011 & 358 & 95 & 18 & 69 \\
2010 & 318 & 65 & 13 & 64 \\
\hline
\end{tabular}

On top of the tourists arriving by air, an additional share of approximately $3 \%$ is generated by visits with ferries. However, these were excluded from the assessment due to both the low impact of ferries in comparison to air travel along with the incompleteness of the data concerning the trips made by sea.

\subsubsection{Local Consumption in Iceland}

The Icelandic Tourism Research Centre (ITRC) provided the main data on the tourist activities in Iceland used in this study. The ITRC collects and publishes annual data about "the activities that typically produce tourism characteristic products" [65], with these activities making up the categories of expenditure for the Icelandic tourism industry. Because there is no specific categorisation of tourism in the Icelandic National Accounts, the categories of expenditure included in this sector are those specified by the UNWTO [59], as shown in Table S1. The annual expenditure under each UNWTO category is calculated by the ITRC by aggregating specific enterprises from the Icelandic industry classification of activities, ISAT 2008. ISAT categorises each enterprise in Iceland with a five-digit code based on European Union's NACE Rev2. The Icelandic codes for the tourism industry are given in Table S1 and show the contributing economic sectors for each category [65].

The expenditure data for inbound tourists was primarily obtained from Statistics Iceland [62]. This data, shown in Table 3, represents the total amount spent by all tourists in the study year (2013) in 
each of the expenditure categories in the Icelandic tourism sector. Due to the high level of aggregation of this data, it was disaggregated into more detailed consumption sectors according to additional information obtained from the Centre for Retail Studies (CRS) [66]. The sub-categories used for this disaggregation are shown in column 2 in Table 3. These sub-categories, spanning the entire tourism sector of Iceland, enabled each of the general Statistics Iceland categories to be separated into their component parts. For this disaggregation, the total expenditure from Statistics Iceland was separated into the sub-categories based on the percentage distribution observed in the CRS dataset. This process produced a more refined dataset for use in the IO model (Section 3.3.1). While the CRS data only included credit card purchases, the source had a more detailed industry sector distribution than the Statistics Iceland data. It was therefore assumed that the information from Statistics Iceland is more comprehensive in terms of total expenditure, but that the distribution of spending across each sub-category shown in the CRS data is valid to disaggregate it. This assumption can be justified as, in Iceland, credit cards are accepted everywhere even for small amounts and are even required for the most important purchases of tourism activities like accommodation, vehicle rentals and tour reservations. Furthermore, since the overall consumption figures are taken from the data from Statistics Iceland, there is no downwards bias of leaving out cash purchases. Table 3 depicts the disaggregation and the resulting consumption estimations. In conjunction with the number of tourists visiting Iceland (Section 3.2.1), this information will be used determine the expenditure in each category for the average tourist.

Table 3. Statistics Iceland disaggregated into CRS subcategories (Million ISK).

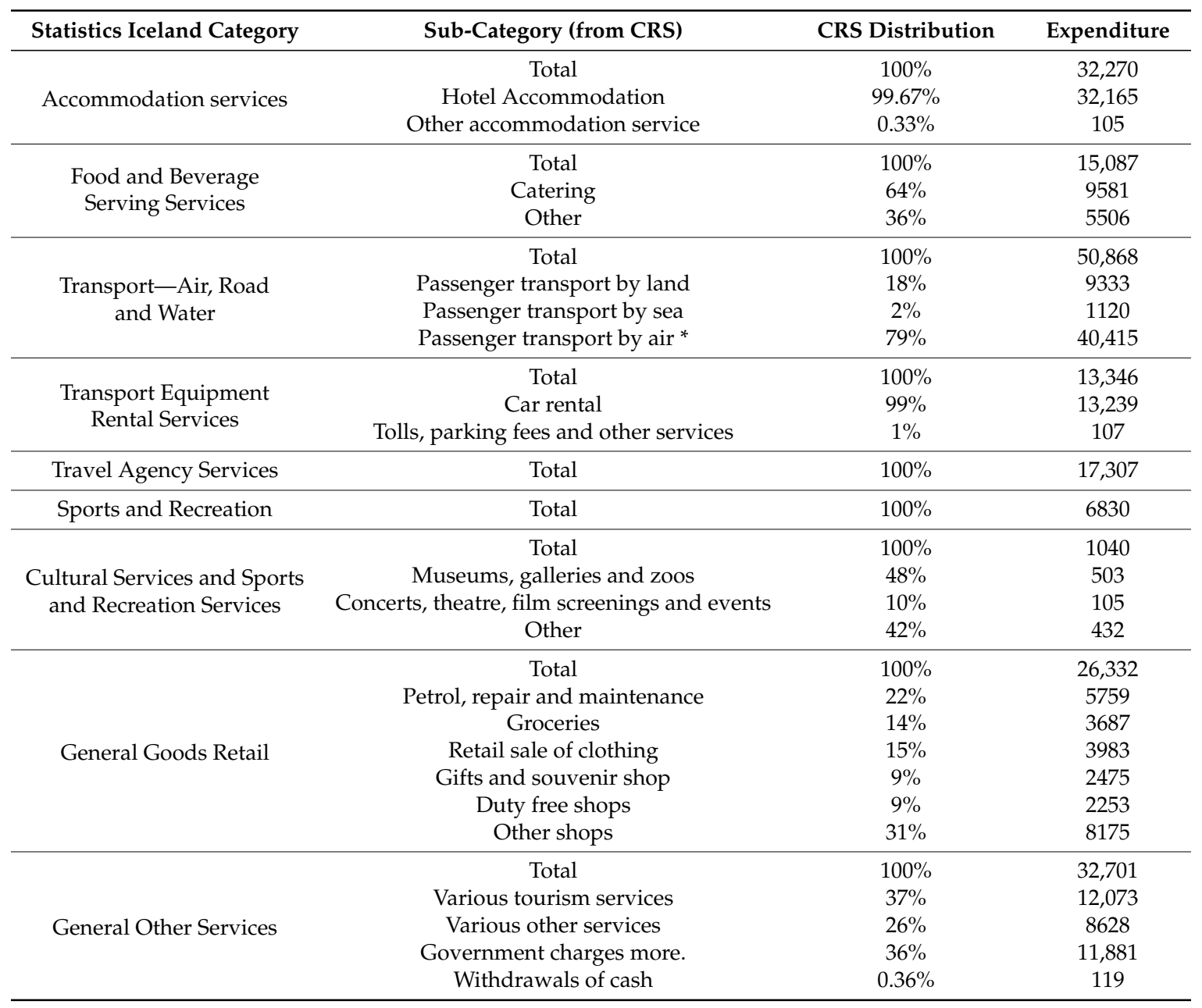

* Replaced with higher resolution data, see Section 3.2.3. 


\subsubsection{Air Travel}

As described in Section 3.2.1, the utilised data includes the top 17 countries for visitors to Iceland and the overall number of visitors to the country. The associated travel distances were estimated by taking the return flight distances to Iceland from a representative airport in each origin country, with the distance for the "Other" or "Unknown" category calculated as a weighted average of these 17 most active countries (Table 4). The potential errors arising from this approach are discussed in Section 5.

Table 4. The selected representative airport cities of the 17 countries with the most visitors to Iceland and the estimated distances to Keflavik International Airport in Iceland. The "Other" category is calculated as a weighted average of the 17 most active countries.

\begin{tabular}{cccc}
\hline Region & Country & City & Distance (km) \\
\hline \multirow{2}{*}{ Asia } & China & Beijing & 7880 \\
& Japan & Tokyo & 8790 \\
\hline \multirow{4}{*}{ Europe } & Denmark & Kopenhagen & 2110 \\
& Finland & Helsinki & 2430 \\
& France & Paris & 2240 \\
& Germany & Frankfurt & 2380 \\
& Italy & Rome & 3300 \\
& The Netherlands & Amsterdam & 2010 \\
& Norway & Oslo & 1740 \\
& Poland & Warsaw & 2770 \\
& Russia & Moscow & 3300 \\
& Spain & Madrid & 2900 \\
& Sweden & Stockholm & 2130 \\
& Switzerland & Geneve & 2640 \\
& United Kingdom & London & 1900 \\
\hline \multirow{2}{*}{ North America } & Canada & Toronto & 4200 \\
& USA & Chicago & 4760 \\
\hline \multirow{2}{*}{ - } & Other & - & 3220 \\
\hline
\end{tabular}

Three representative flight journeys were then constructed, which were used to quantify the range of emissions generated by tourists from different regions due to air travel, shown to be one of the most significant sectors for emissions. These scenarios represent the most common short, medium and long-distance flights arriving in Iceland-the short flight represents departures from the UK, Scandinavia and northern continental Europe, the medium flight represents those from North America and Southern Europe, and the long flight accounts for trips from eastern Asia, South America and Africa. Table 5 depicts the distances for each of these representative scenarios.

Table 5. The average flight scenarios for foreign tourists coming to Iceland.

\begin{tabular}{ccc}
\hline Scenario & Flight Route & Distance (km) (Return Flight) \\
\hline Short & Northern Europe & 2000 \\
\hline Medium & $\begin{array}{c}\text { North America } \\
\text { Southern Europe }\end{array}$ & 4000 \\
\hline \multirow{3}{*}{ Long } & $\begin{array}{c}\text { Asia } \\
\text { South America } \\
\text { Africa }\end{array}$ & 10,000 \\
\hline
\end{tabular}

It was also necessary to determine the plane model(s) that would most likely be used for each of these three flight scenarios. This is due to the substantial differences in fuel, material and associated 
operational requirements necessary for different aircraft used commercially, resulting in vastly different GHG emissions [67]. A review of the global aircraft fleet (comprising of approximately 26,000 aircraft in 2013) revealed the vast majority of commercial aircraft were either Boeing or Airbus models, representing $39.7 \%$ and $28.7 \%$ respectively of all in-service aircraft operating in 2013 [68]. Inspection of a global aircraft census for that year also showed that within these manufacturers, two models dominated the commercial aviation sector-the Airbus A320 family and the Boeing 737 family [69]. In addition to making up almost $60 \%$ of global in-service mainline aircraft in 2013 [69], they are amongst the fastest-growing models used, increasing in number by almost 10\% each between 2014 and 2015 [70]. With these models also used by many airlines connecting to Iceland, it is therefore assumed that these two aircraft types can be taken to represent all flights bringing tourists to Iceland.

\subsection{The Greenhouse Gas (GHG) Assessments}

The calculation methodology used to determine the carbon footprint of tourism in Iceland is described in two parts below. The carbon footprint of the average foreign tourist was first calculated using the EIO LCA 2002 Purchaser Price IO LCA model. The results from this analysis were then used to estimate the total GHG emissions generated by foreign tourism in Iceland in 2013 and approximate the change in emissions that has occurred between 2010 and 2015.

\subsubsection{Carbon Footprint Calculation}

The assessment of the carbon footprint of the average foreign tourist was undertaken using a consumption-based approach $[32,41,46]$ that allocates all emissions from touristic activities to the tourist. This approach was chosen as it recognises that the consumer is the main driver behind demand and without this demand there would be no production.

The tiered hybrid LCA consists of two parts: the IO LCA model, which forms the foundation of the assessment, and process data, which is used to enhance the accurateness of the model. In this study, process data was used for local energy consumed by local service providers and for fuel combustion in rental cars. The remainder of the production and supply chain emissions were assessed with the IO approach. For air travel, the travel distances and emission data from another study were utilised as described in more detail later in this section.

The U.S. industry-based EIO LCA 2002 Purchaser Price IO LCA model [71] was selected as the IO model to form the basis of the hybrid LCA model. According to the IO LCA principles presented in Section 2, the model returns the emissions per one currency unit spent on a certain economic sector using the most common 100 years basis $\left(\mathrm{GWP}_{100}\right)$. The emissions reported by the model includes not only $\mathrm{CO}_{2}$ (fossil and process) but also methane $\left(\mathrm{CH}_{4}\right)$, nitrous oxide $\left(\mathrm{N}_{2} \mathrm{O}\right)$, hydrofluorocarbons (HFCs), perfluorocarbons (PFCs) and sulfur hexafluoride. Therefore, combining the consumption data presented above with representative sectors of the model theoretically produces the total carbon footprint. The U.S.-based EIO LCA model was selected as the basis of the hybrid model as it includes 428 industry sectors (the most sectors of the available models) and can therefore provide better sectoral matches with the consumption data used in this study. Furthermore, the Icelandic economy is strongly import dependent, which diminishes the need to use a local model. Still, the use of this EIO LCA model does introduce some uncertainties due to the model being based on a foreign economy and the data being 10 years old in comparison to the base year of the study. Due to these limitations, certain amendments were made to the IO model itself to enhance the assessment with local or more current process data incorporated to assess the emissions from direct energy use, flights and private driving. Descriptions of the data and the modifications made to the model are provided in the following paragraphs and summarised in Table 6 . These modifications significantly reduced the uncertainties arising from using a 2002 U.S. industry-based model as they cut the share of GHGs assessed directly with EIO LCA to well below 50\% whilst retaining the comprehensiveness of the assessment in including the upstream emissions from production and delivery chains and fixed capital. In this hybridisation process, this study follows examples in the literature including Heinonen and Junnila (2011) [72,73] 
who have utilised the same IO model as a basis of a similar hybrid model for carbon footprint studies in Finland. The amendments and the hybridisation process are explained below, with the remaining uncertainties discussed in Section 5.

To enhance the fit between the 2002 model and the 2013 expenditure data, the sectoral GHG intensities of the model were modified according to sectoral U.S. inflation data for the years 2002-2013 [74] before converting the currency to the Icelandic krona (exchange rate 123.5 ISK/U.S. \$, the average rate during 2013 according to the Central Bank of Iceland). The IO model sectors utilised to assess the emissions from each consumption category are shown in Table S2.

Process LCA data was used to enhance the assessment of service sectors relying on Icelandic energy production, since the energy production system in Iceland is significantly different to that in the U.S., and the majority of all GHGs relate to energy production. An emissions factor of $7.5 \mathrm{~g} \mathrm{CO}_{2}$-eq/ $\mathrm{kWh}$ was retrieved from Björnsson [29] and Karlsdottir et al. [75] and was applied to local services following the tiered hybrid method (see Section 2).

For air travel, the expenditure data was replaced with distances travelled, as explained in the previous section. For the calculation of the carbon footprint, the GHG emission factor per passenger kilometre (PKM) of $135 \mathrm{~g} \mathrm{CO}_{2}$-eq/PKM was taken from Chester and Horvath [76] for the Boeing 737, of which approximately $100 \mathrm{~g} \mathrm{CO}_{2}$-eq/PKM relates to operation and the rest to indirect emissions. According to the authors, this emissions factor is also applicable for use with the Airbus 320 family [76]. Chester and Horvath [76] used a hybrid LCA model to calculate the life-cycle energy use and associated emissions from a range of transport modes and, by adopting this approach, the resulting factors take into account the emissions from manufacturing, operations, maintenance, insurance, infrastructure construction, infrastructure operations and fuel production and combustion. The emissions factor is thus compatible with the EIO LCA and hybrid GHG factors used for other sectors in this study.

Finally, to calculate the emissions from fuel combustion due to driving, a two-fold procedure was followed. Firstly, the emissions from fuel production were assessed with the EIO LCA model. Secondly, since the model is a cradle-to-gate model and excludes the combustion of the fuel, the combustion phase emissions were added by calculating the amount of fuel purchased using the 2013 average petrol price of 254.33 ISK/L [77] and the emissions factor of $2.36 \mathrm{~kg} \mathrm{CO}_{2}$-eq for fuel combustion per litre [78]. The same approach has previously been used in e.g., [72,73].

Table 6. GHG data sources and modifications to the model.

\begin{tabular}{lllll}
\hline Sector & Direct GHGs & Source & Indirect GHGs & Source \\
\hline Local service use & $\begin{array}{l}\text { Icelandic energy } \\
\text { production intensity }\end{array}$ & {$[29,75]$} & $\begin{array}{l}\text { EIO LCA sectors as presented } \\
\text { in SI Table 1, except for energy }\end{array}$ & {$[71]$} \\
\hline $\begin{array}{l}\text { Private driving } \\
\text { fuel combustion }\end{array}$ & $\begin{array}{l}\text { Tailpipe emissions from } \\
\text { fuel combustion }\end{array}$ & {$[79]$} & $\begin{array}{l}\text { Fuel production and delivery } \\
\text { with EIO LCA }\end{array}$ & {$[71]$} \\
\hline Air travel & $\begin{array}{l}\text { Aircraft operation } \\
\text { according to trip distances }\end{array}$ & {$[76]$} & $\begin{array}{l}\text { Aircraft and fuel manufacture, } \\
\text { infrastructure }\end{array}$ & {$[76]$} \\
\hline All other activities & $\begin{array}{l}\text { EIO LCA as presented } \\
\text { in SI Table 1 }\end{array}$ & {$[71]$} & $\begin{array}{l}\text { EIO LCA as presented } \\
\text { in SI Table 1 }\end{array}$ & {$[71]$} \\
\hline
\end{tabular}

For presentation of the results, the consumption categories in Table 2 were combined into five sectors as follows:

(1) Air travel

(2) Local transport

(3) Accommodation and restaurant services

(4) Retail goods

(5) Recreation and leisure services. 


\subsubsection{Overall Tourism-Induced GHG Estimation}

In the second stage, the total GHG emissions from foreign tourism in Iceland for 2013 were assessed along with the change in emissions between 2010 and 2015. The 2013 per capita emissions were used as the basis for calculating the change in emissions over the entire period 2010-2015. While the expenditure per tourist in Iceland has moderately increased during 2010-2013 [62], it is appropriate to assume that the tourist activities in the assessment period 2010-2015 align with those in the base year. This assumption allows the overall GHG impacts of tourism for the whole period to be calculated using the 2013 estimates. This assumption has also been utilised to project future environmental impacts from tourism in New Zealand by Patterson and McDonald [9].

For flights, the GHG emissions were estimated according to the country-by-country distances explained in Section 3.2.3 (for "Other" as a weighted average of the 17 countries). For presentation, the visitors were comprised into four groups as follows:

(1) Europe

(2) North America

(3) Asia

(4) Other

For presentation purposes, in this stage, the carbon footprints were further aggregated into just two sectors, "Air travel" and "Within-country consumption".

\section{Results}

The results of the study are presented below in two sections in line with the objectives of the study which were to (1) estimate the carbon footprint of the average foreign tourist in Iceland; and (2) estimate the overall annual GHG impact caused by tourism to Iceland between 2010 and 2015. The results in Section 4.1 relate specifically to the average tourist (as defined in Section 3.1) and have been aggregated into the five consumption categories described above. The total carbon footprint of the Icelandic tourism sector is described in Section 4.2 and relates to the overall emissions from the sector for the base year and the variations observed over time.

\subsection{The Carbon Footprint of an Average Tourist Visiting Iceland}

According to this study, the per capita carbon footprint of an average tourist visiting Iceland in the year 2013 was $1350 \mathrm{~kg} \mathrm{CO}_{2}$-eq. However, depending on the flight scenario modelled, the carbon footprint ranged from $1090 \mathrm{~kg} \mathrm{CO}_{2}$-eq for the short-flight scenario (representing the second most common country of origin, the UK, and northern Europe) to a maximum of $3250 \mathrm{~kg} \mathrm{CO}_{2}$-eq for the long-flight scenario representing a departure from Asia or South America. For the medium-flight scenario, which covers departures from the most common ports in the USA, an average carbon footprint of $1600 \mathrm{~kg} \mathrm{CO}$-eq was calculated. In the three scenarios, it was found that flights alone accounted for $50 \%$ to $83 \%$ of the total emissions, or 540 to $2700 \mathrm{~kg} \mathrm{CO}_{2}$-eq respectively. When these results were inspected further, it was found that more than $75 \%$ of the emissions were solely due to aircraft operations, with the remainder in this sector due to aircraft manufacture, operations, infrastructure construction and fuel production.

Local transport was found to be the second-largest source of emissions due to the associated fossil fuel combustion. The emissions caused by this sector are $330 \mathrm{~kg} \mathrm{CO}_{2}$-eq per tourist according to the assessment. Even though these emissions form only a relatively small share of the total, the amount is actually very high given the short duration of the visit. Of these emissions, approximately $30 \%$ comes from the fuel combustion of rental cars with $60 \%$ due to sightseeing bus tours and local public transport. Sightseeing boat trips add the majority of the remaining $10 \%$. Notable exclusions from the transport emissions calculations are those due to travelling to and from the airport in the home country of the tourist; however, the contribution of this element can be considered negligible [23]. Together, the GHGs from the two transport sectors form a share of $83 \%$ to $93 \%$ of the overall carbon footprint. 
Accommodation and restaurant services sector is the main sector that benefits from the nearly zero carbon energy system of Iceland. This feature means that the GHG emissions from the accommodation sector are only $100 \mathrm{~kg} \mathrm{CO}_{2}$-eq, or just $3 \%$ to $8 \%$ of the total depending on the flight scenario. Retail goods add $70 \mathrm{~kg} \mathrm{CO}$-eq to the total according to this assessment. Even though the uncertainty related to the assessment method is perhaps the highest with regard to this sector, it is evident that the importance of tangible goods purchased by tourists in Iceland is low in comparison to other sectors.

Finally, Recreation and leisure services, also gaining from the low-carbon energy sector, contribute the lowest emissions of the sectors analysed, accounting for approximately $50 \mathrm{~kg}$ of $\mathrm{CO}_{2}$-eq, or $1.5 \%$ to $4 \%$ of the carbon footprint. The low contribution of this sector also relates strongly to the choice in this study to combine all local transport emissions into one sector. It should be noted that an important share of the local transport category is made up by recreation and leisure services, but in this study, treating all transport separately was seen to be more informative. Figure 1 depicts the GHGs from the five sectors per average tourist, separating the three flight scenarios.

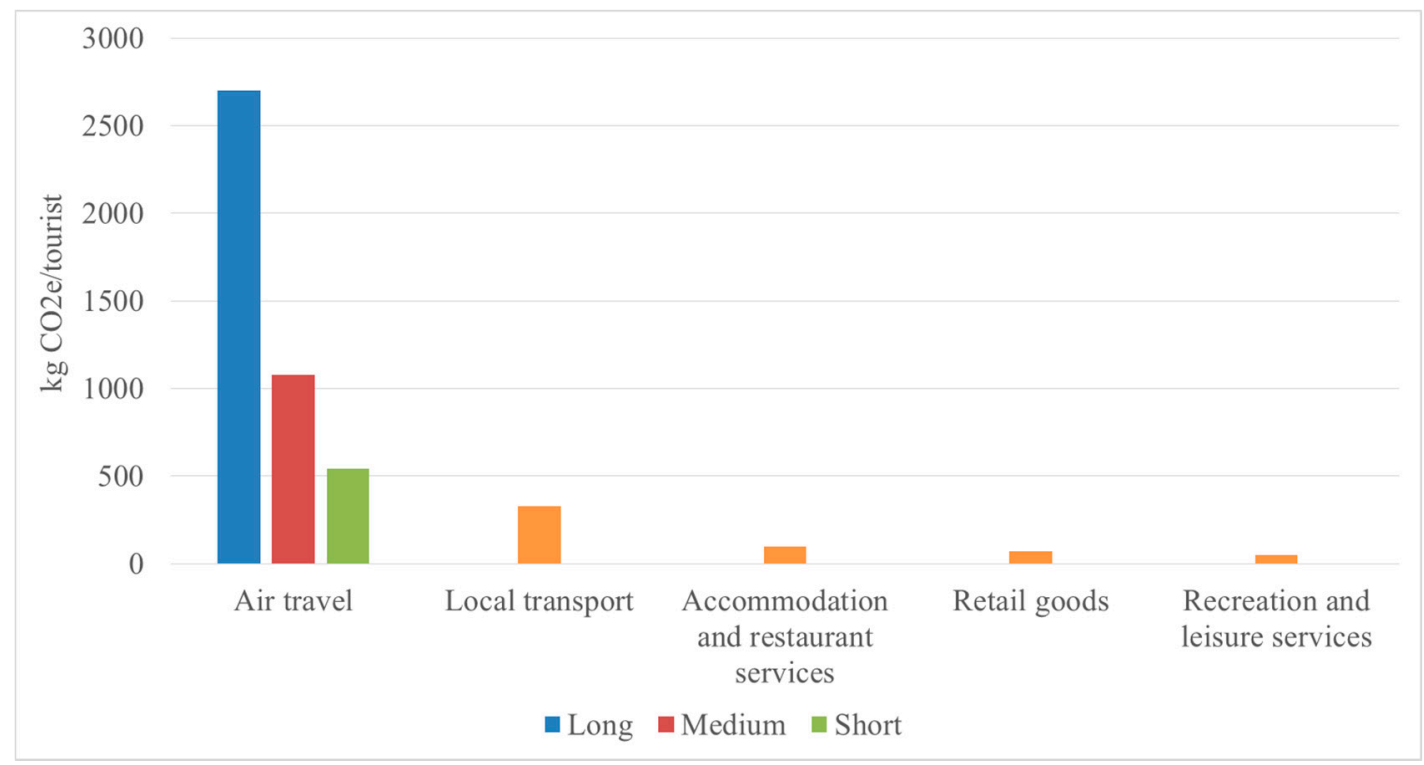

Figure 1. The distribution of the carbon footprint of the average foreign tourist in Iceland for 2013.

\subsection{The Overall GHG Impact of Tourism to Iceland}

While the carbon footprint of a single average tourist seems to be relatively high (discussed further in Section 5), the overall emissions from tourism and the patterns of variations are more often the focal issues for climate change. The annual number of tourist visits to Iceland has been rapidly increasing over the past five years, with similar or higher growth rates estimated to occur in the near future. The average annual growth rate has been almost $20 \%$ since 2010 , and the rate is consistently increasing, reaching 30\% in 2015 and remaining at over 30\% in the first half of 2016 [47]. The number of tourist visits exceeded one million for the first time in 2014 but in 2015 this point was surpassed by August-September [47]. Over 50\% of the visitors still arrive from within Europe, but the relative share of total visitors arriving from this region has been declining, even though the number of tourists from Europe more than doubled in 2010-2015. This fall in the European share is due to the rapid growth rate in the number of tourists arriving from Asia and North America. This shift magnifies the GHG impact observed, as an average return flight increased from $750 \mathrm{~kg}$ to $870 \mathrm{~kg}$ between 2010 and 2015 . Figure 2A shows the numbers of tourists according to the area of origin from 2010 to 2015 and 2B the GHG development. 


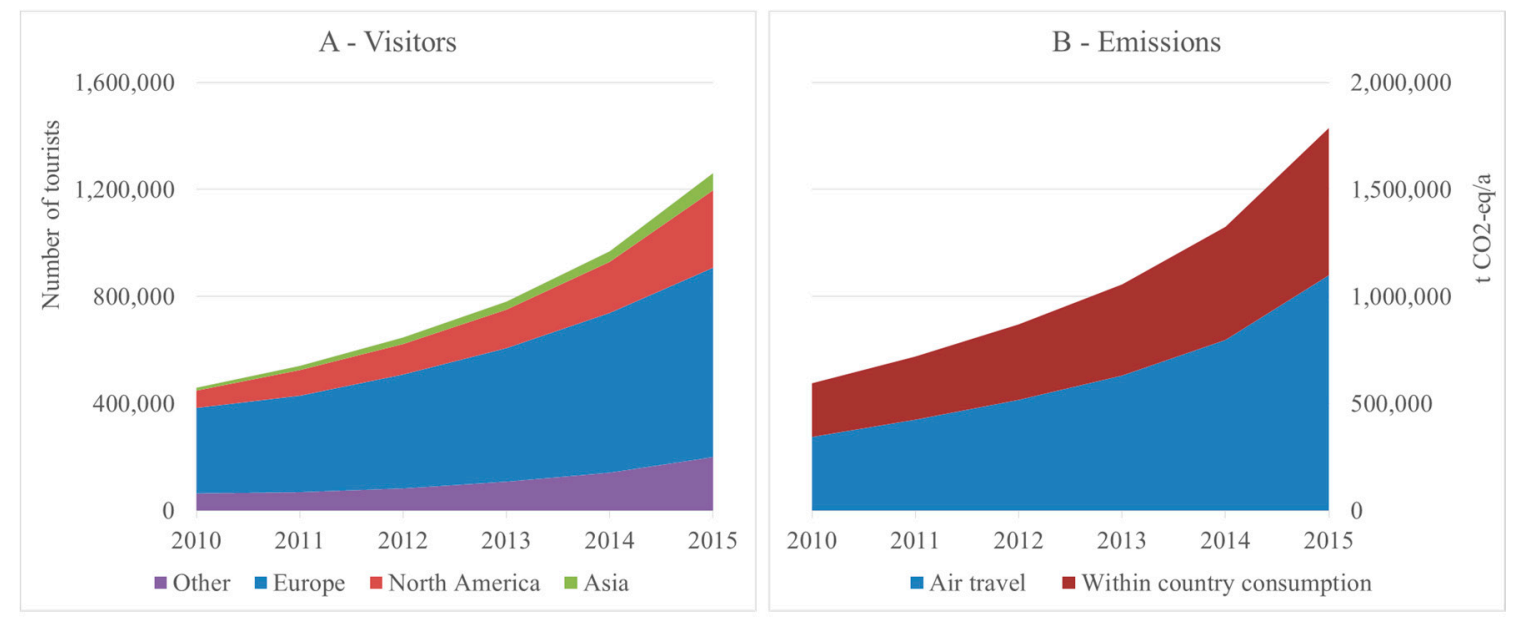

Figure 2. Number of tourists to Iceland in 2010-2015 and the overall GHG emissions: (A) number of tourists; (B) the annual GHG emissions.

According to this study, the total annual GHG load caused by tourism to Iceland has tripled in just five years, rising from approximately 600,000 tons $\mathrm{CO}_{2}$-eq in 2010 to 1,800,000 tons in 2015. Cumulatively this means 6.4 million tons of $\mathrm{CO}_{2}$-eq have been emitted due to tourism to Iceland during this time. The rise in the GHG emissions and the cumulative emissions over this time period are shown in Figure 2B.

Finally, when considering the emissions related to tourism in Iceland, it should be noted that not all emissions are additional to normal levels on a global scale. A proportion of the emissions will be relocated from the tourist's country of origin and would have occurred even if the trip did not take place. It can be assumed that passenger transport, related vehicle activities and groceries will be consumed by individuals regardless of whether or not they are on holiday. These sectors account for approximately $10 \%$ of the total emissions calculated in this study.

\section{Discussion}

The aim of this study was to present a consumption-based carbon footprinting method to assess the total GHG impact of tourism for a country, including direct and indirect emissions. The approach is applicable to other destinations as well, but in this study Iceland was used as the case country due to its unique nature as an isolated island nation and almost $100 \%$ renewable sources-based local energy system.

The results indicate that transport is, by far, the largest source of emissions. The dominance of aviation emissions clearly demonstrates the strong influence that the point of departure of a tourist has on the final carbon footprint. This finding is especially concerning given the trend towards more tourists arriving from outside of Europe. In-country transport is also notable, especially given the short duration of travel. As noted by [19], the length of stay is an important factor in assessing the carbon impact of tourism, with longer stays enhancing the overall carbon efficiency of travel [80].

From a climate change mitigation policy perspective, this study finds on average $70 \%$ of the GHGs caused by an individual tourist to be due to air travel and thus the emissions currently fall outside of any domestic mitigation policies. This also means that any local mitigation policies in Iceland (or any other similar destination) will affect only a minor share of the total emissions. The GHG emissions from air travel in 2013 were already larger than the total tourism-related emissions in 2010 and the share of air travel is also the most rapidly growing sector due to the shift in the countries of origin towards North America and Asia. This has resulted in a disproportionate rise in emissions-while the growth rate in number of visits has increased from 2010 to 2015 from below 20\% to 30\%, the growth in emissions has risen significantly from $20 \%$ to well above $30 \%$. 
Furthermore, this study found that of the remaining $30 \%$ of total emissions, the majority relate to fuel combustion in local transport. These emissions are likely to largely remain for a long time despite the initial discussions about electrification of the transport sector in Iceland. As local transport is used by the majority of tourists visiting Iceland [29], addressing this sector will be vital when developing local emission mitigation strategies. The low emissions stemming from the accommodation, retail and activities sectors due to Iceland's almost carbon-free energy system also suggest that focussing on transport will produce the largest reduction in the part of the carbon footprint within reach of local mitigation policies. Rapid growth in tourism also boosts construction activity and potentially leads to high emissions from the construction sector, but the issue should be studied further to understand well enough the emissions and the mitigation potentials.

The findings of this study regarding the carbon significance of transport activities are in line with other examples in the literature. International aviation was reported as the dominant source of emissions by many other studies on the topic (e.g., [5,7-10,12,20]), including the UNWTO-UNEP-WMO [59], where it was shown to account for up to $50 \%$ of total tourism emissions globally. Aviation's share of total emissions in the present study are also similar in magnitude to other island nations as summarised by Gössling [13], which may be a more meaningful comparison. Other transport modes, including road and water travel, car rental and other related activities, were also generally found to be the second-largest source of emissions (e.g., [18,29]). Gössling [7] also found that transport (both road, sea and air) could contribute $90 \%$ of total emissions, even when indirect emissions were excluded, with a figure of $75 \%$ reported in the Helsingborg Statement on Sustainable Tourism. The only exception are the results from UNWTO-UNEP-WMO [18], which show similar relative emissions between the "other transport" and "accommodation" sectors. In Iceland, conversely, the local low-carbon energy system automatically pushes more relative weight to ground transport. Due to the different calculation methodologies and system boundaries adopted across the literature [13], further comparison of the less emissions-intensive sectors (e.g., accommodation, retail, etc.) was not attempted. Table S3 summarises some of the similarities and differences in the results of this study and previous studies found from the literature.

The overall carbon footprints calculated were also compared to those found by Bjönsson [29], who modelled the emissions resulting from three different trip itineraries. The results of [29] ranged between 400 and $1300 \mathrm{~kg} \mathrm{CO}_{2}$-eq per capita for the trips comparable to the one assessed in this study, which emitted an average of 1.35 ton $\mathrm{CO}_{2}$-eq per capita. The similar per capita emissions found by the two studies goes some way towards validating the findings of the current analysis. Furthermore, the lower results obtained by [29] are to be expected due to the broader scope of the current study. Most importantly, only the direct emissions were calculated in [29], meaning the results underestimate the true emissions to some extent, especially in regards to transport. In addition, no long-distance flights from Asia were included in the assessment and the emissions due to retail and consumption were also omitted.

In the second part of this study, it was estimated that the total GHG load caused by tourism to Iceland has boomed from 0.6 million tons $\mathrm{CO}_{2}$-eq to 1.8 million tons $\mathrm{CO}_{2}$-eq between 2010 and 2015 (Figure 2B). This is significant especially when compared to Iceland's total emissions in 2012 of 4.6 million tons $\mathrm{CO}_{2}$-eq, a figure that largely omits air travel. Also noticeable from the results of this study is that the overall GHG load due to tourism is not growing fast just because of the rise in visits to Iceland, but also because of the increase in the relative share of tourists coming from farther away (Figure 2A). It was also assumed that all flights from Europe and North America were direct. In reality, such an assumption leads to an underestimation of the aviation-related emissions, but without proper data on the connection flights, this weakness was accepted.

Overall, the reliability of the study and results were assessed in terms of the limitations and uncertainties related to the model itself, study design and the input data used. The applicability of the hybrid LCA method for consumption-based assessments has been shown to be appropriate based on other studies in the literature (e.g., [72,73,81]). However, as no local model was available, this study 
utilised a U.S.-based model, which raises an issue regarding compatibility. The EIO LCA model was selected for several reasons, which support its applicability. First, of the available models, the EIO LCA provides the most disaggregated set of industry sectors, which reduces the aggregation error, one of the main deficiencies of the IO method [52]. This meant that the integrity of the input data could be maintained as much as possible. Second, the EIO LCA enables enhancements to be made by using local data. In this assessment, the utilisation of local energy data in the model significantly reduces the compatibility uncertainty, since the vast majority of GHGs are due to the energy sector. Third, as the majority of goods consumed in Iceland is imported, a local model is unlikely to produce significantly different results; the U.S. is already the second-largest import trade partner to Iceland. Finally, the assessment was further improved through the calculation of the emissions from air travel with distance data and the GHG intensity from Chester and Horvath [76], and inclusion of the emissions from fuel combustion of rental cars based on litres of fuel purchased. These modifications reduced the direct EIO LCA share in the assessment results from 15\% in the long-flight scenario to $29 \%$ in the medium scenario and $46 \%$ in the short scenario, meaning the use of another model would most likely not change any of the suggested implications significantly. Notwithstanding, as the model is based on 2002 economic information, there are still inaccuracies in the results due to changes in the economic or environmental data over time. To reduce these uncertainties, sectoral inflation corrections were applied to each industry sector of the model for the years 2002-2013 before applying a monetary exchange rate conversion. While this does not fully remove the uncertainty, it does significantly reduce it.

When using the IO LCA approach, converting monetary values into GHG emissions contains uncertainty as well. The inherent deficiencies of IO LCA (homogeneity and linearity assumptions e.g., [51]) means that all products from one IO model industry sector are assumed to have the same GHG intensity per monetary unit. Furthermore, the emissions load is assumed to linearly increase with an increase in expenditure. If the purchased products are very different from the industry average, the model might randomly under- or overestimate the emissions. In the current study, however, the key sectors (aviation and private vehicle use) are not subject to this uncertainty, meaning the impact should be limited.

Regarding the input data, the expenditures were predominantly sourced from Statistics Iceland, which suggests a high level of reliability. While the data was only sourced for a single year in this analysis (2013) and could therefore suffer from temporal variability, the overall tourist spending in Iceland has remained relatively stable between 2010 and 2015, thereby indicating a low risk of this error. Furthermore, the calculated GHG impact of tourism in Iceland is an average figure, with no specific data included on trip length, activities undertaken or accommodation preferences. With other studies indicating the importance of certain factors such as trip length on the overall emissions intensity of tourism (e.g., [23]), further work is required to understand the sensitivity of the emissions to these variables. This would likely require more thorough, accurate and up-to-date data collection on the actual behaviour of tourists [23].

Certain sources of GHG emissions were also excluded from the analysis (see Table 2), suggesting that the results derived in this study underestimate the true emissions to some extent. For example, transport in the tourist's country of origin, potential accommodation before the flight and connection flights (which increase the distances travelled) were not covered in this analysis due to a lack of data. Furthermore, the analysis method used is unable to explicitly account for the additional infrastructure and buildings, especially hotels, constructed as a result of tourism expansion. The IO method inherently includes the capital costs and thus the emissions related to the fixed capital of each sector, but increasing construction activity due to tourism expansion would only be apparent in an up-to-date model. Therefore, although some construction-related emissions are captured in the IO model, it is reasonable to assume that the accommodation services sector in particular may generate higher emissions than shown in this study due to rapid construction of new accommodation facilities to meet the increasing demand. IO models, including EIO LCA, are typically cradle-to-gate models. This means that there 
might be a downwards bias in the results they produce, as emissions that occur during the "use" or "end-of-life" phase are excluded. In this study, as the use of rental vehicles was calculated separately, additional emissions occurring during this phase are covered. The end-of-life phase is the most uncertain. To some extent, the prices tourists pay include end-of-life costs and the related emissions are determined by IO matrices which include the recycling and waste treatment sectors. However, how well the actual end-of-life emissions are reflected in this approach cannot be easily estimated. Typically, the end-of-life phase is the least important in terms of GHGs [37] and thus this uncertainty should not compromise any findings or potential policy guidelines based on the results reported in this study.

It should also be noted that the tourism sector likely generates environmental impacts in addition to GHG emissions, all of which have been excluded from this study, as well as various social impacts. Several studies reviewed for this paper identified land use, biodiversity loss, water consumption, pollution and cultural issues as significant consequences of tourism in addition to energy use and emissions [7,9]. For example, Patterson \& McDonald [9] found that tourism ranked 6th out of the 25 sectors assessed in terms of land use impact, with Gössling [7] calculating that the sector contributed to $0.5 \%$ of global loss of biologically productive land (mostly from transport-related infrastructure). It has also been shown that tourism leads to significantly higher rates of water consumption, with some tourists in Europe consuming up to $800 \mathrm{~L} /$ day compared to the average daily consumption of just $241 \mathrm{~L} /$ day [4]. While examination of these issues was beyond the scope of this study, such an analysis is required to fully understand and address the impacts caused by the rapidly expanding tourism sector in Iceland.

Finally, the assumptions behind the international air travel emissions factors do have a significant impact on the result due to the dominance of this sector. The selected source Chester and Horvath [76] was validated with the intensities used by Ottelin et al. [82] and Lewis [67] with the result that Chester and Horvath estimate the emissions somewhat lower (operation $98 \mathrm{~g} \mathrm{CO}_{2}$-eq/PKT vs. 114-149 $\mathrm{g} \mathrm{CO}_{2}$-eq/PKT in [82] and the whole life cycle $135 \mathrm{~g} \mathrm{CO}_{2}$-eq/PKT vs. $180.5 \mathrm{~g} \mathrm{CO}_{2}$-eq/PKT in [67]), thus suggesting that air travel is not over-emphasised in this study. However, PKT as a unit is still potentially problematic. There is no information available on whether the average occupancy rates of flights to Iceland comply with those used by Chester and Horvath [76], and large deviations could lead to significant estimation errors. This uncertainty cannot be overcome in this study. An additional interesting perspective on air travel is that the climate change impact would be much higher than current GHG intensities imply since they are calculated using the same approach as for ground vehicles. In fact, if certain short-lived GHGs and the cloud-forming impacts were accounted for, the impacts per passenger kilometre would be significantly higher [83]. For example, Lee et al. [83] have suggested multipliers of 1.3 to 4.8 for the impacts of aviation. If this were the case, it would further increase the significance of the findings in this study regarding the impact of air travel. As the tourism sector accounts for at least half of global aviation emissions and is likely to rise, determining the correct multipliers is a critical issue to resolve [84].

\section{Conclusions}

This study was intended to enhance the understanding of the environmental impact caused by tourism on both a local and global scale. The presented approach is also applicable elsewhere, meaning the method carries added value to the research field. The results of the study should not be interpreted as a criticism of the tourism industry, but rather as a demonstration of a method to study the GHG impact of the sector and provide the necessary information to develop appropriate mitigation policies. It is of high importance during the present day to study and bring into discussion those perspectives not necessarily captured with the most widely utilised assessment schemes, such as the Kyoto protocol-based assessments and reporting with regards to GHGs. With aviation, there is currently little scope for direct intervention locally as there are few other means of transport to Iceland and there is currently no international framework for attributing aviation emissions to individual 
economies. For example, Iceland has set an EU-collective 40\% GHG reduction target to be achieved by 2030 for local emissions. However, when looking at the growth pattern of GHGs from tourism to Iceland, even if this local target could be successfully reached, it is likely to be overwhelmed by the concurrent rise in emissions from aviation due to tourism to the country.

With domestic passenger vehicle use, the second most important emissions sector, there are opportunities for rental agencies to reduce emissions with policies or strategies targeting, for example, changes in fuel mix, technology (e.g., electric vehicles) or fuel efficiency standards. These are often much wider scale policy issues, but according to Shafiei et al. [78], the overall transition towards a low-carbon transport system in Iceland would be both environmentally and economically beneficial.

In addition, those involved in the tourism industry (for example, accommodation providers) can improve the efficiency of operations in areas like building energy efficiency and directing a higher share of procurement to locally produced goods instead of imports, enabling the low-carbon-energy system to benefit from a higher share of the purchased goods. Finally, as emissions from this industry are primarily demand-driven by the tourists themselves, personal consumption and individual choices also offer an important opportunity for reducing emissions. A higher degree of sharing of goods during tourist visits could provide an important channel to reduce the personal impact, as recently shown by Ala-Mantila et al. [85]. For example, car and accommodation sharing services could reduce the need for vehicles and new accommodation facilities, and ride sharing could reduce fuel consumption per capita. Increased awareness of the impacts of various choices and activities should be better promoted by the tourism industry to enable consumers to understand their effect on global emissions and make informed choices.

Further work is recommended to refine this study specifically through the inclusion of manufacturing of imports. Analysis of the additional construction undertaken as a response to tourism expansion could also better inform understanding of the impact of the sector, along with an expansion of the analysis to include additional environmental impacts.

Supplementary Materials: The following are available online at www.mdpi.com/2071-1050/8/11/1147/s1, Table S1: Structure of tourism sector in Icelandic National Accounts, Table S2: EIO LCA categories and other data sources, Table S3: Comparison of results with other studies.

Acknowledgments: The authors thank the Academy of Finland (Grant 286747) for supporting the study.

Author Contributions: The first and the second author collected the data, ran the majority of the assessments, and wrote the first manuscript. The third author acted as their instructor, conducted the final assessments and participated in writing the paper.

Conflicts of Interest: The authors declare no conflicts of interest.

\section{References}

1. United Nations Environment Programme (UNEP). Climate Change: Introduction. Available online: http://www.unep.org/climatechange/Introduction.aspx (accessed on 6 October 2015).

2. Intergovernmental Panel on Climate Change (IPCC). Climate Change 2014: Impacts, Adaptation, and Vulnerability. Part A: Global and Sectoral Aspects. Contribution of Working Group II to the Fifth Assessment Report of the Intergovernmental Panel on Climate Change; Field, C.B., Barros, V.R., Dokken, D.J., Mach, K.J., Mastrandrea, M.D., Bilir, T.E., Chatterjee, M., Ebi, K.L., Estrada, Y.O., Genova, R.C., et al., Eds.; Cambridge University Press: Cambridge, UK; New York, NY, USA, 2014; p. 1132.

3. U.S. EPA. Climate Change: Basic Information. Available online: http:/ /www3.epa.gov/climatechange/ basics (accessed on 6 October 2015).

4. World Tourism Organisation. UNWTO Annual Report 2014; UNWTO: Madrid, Spain, 2014.

5. Dwyer, L.; Forsyth, P.; Spurr, R.; Hoque, S. Estimate the carbon footprint of Australian tourism. J. Sustain. Tour. 2010, 8, 355-376. [CrossRef]

6. Becken, S. Analysing international tourist flows to estimate energy use associated with air travel. J. Sustain. Tour. 2002, 10, 114-131. [CrossRef]

7. Gössling, S. Global environmental consequences of tourism. Glob. Environ. Chang. 2002, 12, 283-302. [CrossRef] 
8. Becken, S.; Patterson, M. Measuring national carbon dioxide emissions from tourism as a key step towards achieving sustainable tourism. J. Sustain. Tour. 2006, 14, 323-338. [CrossRef]

9. Patterson, M.G.; McDonald, G. How Clean and Green Is New Zealand Tourism? Lifecycle and Future Environmental Impacts; Landcare Research Science Series, No. 24; Manaaki Whenua Press: Lincoln, New Zealand, 2004.

10. De Bruijn, K.; Dirven, R.; Eijgelaar, E.; Peeters, P. Travelling Large in 2012-The Carbon Footprint of Dutch Holidaymakers in 2012 and the Development Since 2002. Available online: http:/ / www.cstt.nl/userdata / documents/cstt2013_travellinglargein2012_lowres.pdf (accessed on 17 November 2015).

11. Cadarso, M.A.; Gómez, N.; López, L.A.; Tobarra, M.A.; Zafrilla, J.E. Quantifying Spanish tourism's carbon footprint: The contributions of residents and visitors: A longitudinal study. J. Sustain. Tour. 2015, 23, 922-946. [CrossRef]

12. Sun, Y.-Y. A framework to account for the tourism carbon footprint at island destinations. Tour. Manag. 2014, 45, 16-27. [CrossRef]

13. Gössling, S. National emissions from tourism: An overlooked policy challenge? Energy Policy 2013, 59, 433-442. [CrossRef]

14. Scott, D.; Hall, C.M.; Gössling, S. A review of the IPCC Fifth assessment and implications for tourism sector climate resilience and decarbonisation. J. Sustain. Tour. 2016, 24, 8-30.

15. Simpson, M.C.; Gössling, S.; Scott, D.; Hall, C.M.; Gladin, E. Climate Change Adaptation and Mitigation in the Tourism Sector: Frameworks, Tools and Practices; UNEP, University of Oxford, UNWTO, WMO: Paris, France, 2008.

16. Perch-Nielsen, S.; Sesartic, A.; Stucki, M. The greenhouse gas intensity of the tourism sector: The case of Switzerland. Environ. Sci. Policy 2010, 13, 131-140. [CrossRef]

17. Scott, D.; Peeters, P.; Gössling, S. Can tourism deliver its "aspirational" greenhouse gas emission reduction targets? J. Sustain. Tour. 2010, 18, 393-408. [CrossRef]

18. UNWTO-UNEP-WMO. Climate Change and Tourism-Responding to Global Challenges; The World Tourism Organization and The United Nations Environment Programme: Madrid, Spain, 2008.

19. Filimonau, V.; Dickinson, J.E.; Robbins, D.; Reddy, M.V. A critical review of methods for tourism climate change appraisal: Life cycle assessment as a new approach. J. Sustain. Tour. 2011, 19, 301-324. [CrossRef]

20. Filimonau, V.; Dickinson, J.; Robbins, D.; Reddy, M.V. The role of 'indirect' greenhouse gas emissions in tourism: Assessing the hidden carbon impacts from a holiday package tour. Transp. Res. Part A 2013, 54, 78-91. [CrossRef]

21. Wood, F.; Bows, A.; Anderson, K. How can $\mathrm{CO}_{2}$ emissions from aviation be allocated to regional administrations for monitoring and target setting? In Proceedings of the European Transport Conference 2008, Noordwijkerhout, The Netherlands, 6-8 October 2008.

22. International Civil Aviation Organization. Report on Voluntary Emissions Trading for Aviation (VETS Report). 2007. Available online: http://www.icao.int/environmental-protection/Documents/Measures/ vets_report1.pdf (accessed on 17 November 2015).

23. Filimonau, V.; Dickinson, J.; Robbins, D. The carbon impact of short-haul tourism: A case study of UK travel to Southern France using life cycle analysis. J. Clean. Product. 2014, 64, 628-638. [CrossRef]

24. Hunter, C.; Shaw, J. The ecological footprint as a key indicator of sustainable tourism. Tour. Manag. 2007, 28, 46-57. [CrossRef]

25. Becken, S.; Simmons, D.; Frampton, C. Energy use associated with different travel choices. Tour. Manag. 2003, 24, 267-277. [CrossRef]

26. Kelly, J.; Williams, P.W. Modelling tourism destination energy consumption and greenhouse gas emissions: Whistler, British Columbia, Canada. J. Sustain. Tour. 2007, 15, 67-90. [CrossRef]

27. Jones, C.; Munday, M. Exploring the environmental consequences of tourism: A satellite account approach. J. Travel Res. 2007, 46, 164-172. [CrossRef]

28. Gössling, S. Ecological footprint analysis as a tool to assess tourism sustainability. Ecol. Econ. 2002, 43, 199-211. [CrossRef]

29. Björnsson, V.J. Estimated Carbon Footprint of Foreign Tourists in Iceland-A Bottom-Up Analysis of Direct $\mathrm{CO}_{2}$ Emissions; University of Iceland: Reykjavik, Iceland, 2014.

30. WRI WBCSD—World Resources Institute \& World Business Council for Sustainable Development. The Greenhouse Gas Protocol: A Corporate Accounting and Reporting Standard; World Resources Institute: Washington, DC, USA, 2001. 
31. Ala-Mantila, S.; Heinonen, J.; Junnila, S. Relationship between urbanization, direct and indirect greenhouse gas emissions, and household expenditures: A multivariate analysis. Ecol. Econ. 2014, 104, 129-139.

32. Baynes, T.; Wiedmann, T. General approaches for assessing urban environmental sustainability. Curr. Opin. Environ. Sustain. 2012, 4, 458-464. [CrossRef]

33. Junnila, S.I. Empirical Comparison of Process and Economic Input-Output Life Cycle Assessment in Service Industries. Environ. Sci. Technol. 2006, 40, 7070-7076. [CrossRef] [PubMed]

34. Lenzen, M.; Dey, C. Truncation error in embodied energy analyses of basic iron and steel products. Energy 2000, 25, 577-585. [CrossRef]

35. Lenzen, M.; Murray, S.A.; Korte, B.; Dey, C.J. Environmental impact assessment including indirect effects-A case study using input-output analysis. Environ. Impact Assess. Rev. 2003, 23, 263-282. [CrossRef]

36. Matthews, H.S.; Hendrickson, C.T.; Weber, C.L. The Importance of Carbon Footprint Estimation Boundaries. Environ. Sci. Technol. 2008, 42, 5839-5842. [CrossRef] [PubMed]

37. Lenzen, M. Errors in conventional and input-output-based life-cycle inventories. J. Ind. Ecol. 2000, 4, 127-148. [CrossRef]

38. Gössling, S. Carbon neutral destinations: A conceptual analysis. J. Sustain. Tour. 2009, 17, 17-37. [CrossRef]

39. Rosenblum, J.; Horvath, A.; Hendrickson, C. Environmental implications of service industries. Environ. Sci. Technol. 2000, 34, 4669-4676. [CrossRef]

40. Spielmann, M.; Scholz, R.W. Life cycle inventories of transport services. Int. J. Life Cycle Assess. 2005, 10, 85-94. [CrossRef]

41. Wiedmann, T.; Minx, J. A Definition of 'Carbon Footprint'. In Ecological Economics Research Trends; Nova Science Publishers: Hauppauge, NY, USA, 2008; Chapter 1; pp. 1-11.

42. Kuo, N.W.; Chen, P.H. Quantifying energy use, carbon dioxide emission, and other environmental loads from island tourism based on a life cycle assessment approach. J. Clean. Product. 2009, 17, 1324-1330. [CrossRef]

43. Schianetz, K.; Kavanagh, L.; Lockington, D. Concepts and tools for comprehensive sustainability assessments for tourism destinations: A comparative review. J. Sustain. Tour. 2007, 15, 369-389. [CrossRef]

44. Filimonau, V. Life Cycle Assessment. In The Routledge Handbook of Tourism and Sustainability; Hall, M., Gössling, S., Scott, D., Eds.; Routledge: Oxford, UK, 2015; pp. 209-220.

45. Bullard, C.; Penner, P.; Pilati, D. NET ENERGY ANALYSIS: Handbook for Combining Process and Input-Output Analysis. Resour. Energy 1978, 1, 267-313. [CrossRef]

46. Minx, J.; Wiedmann, T.; Wood, R.; Peters, G.; Lenzen, M.; Owen, A.; Scott, K.; Barrett, J.; Hubacek, K.; Baiocchi, G.; et al. Input-output analysis and carbon footprinting: An overview of applications. Econ. Syst. Res. 2009, 21, 187-216. [CrossRef]

47. Icelandic Tourist Board. Numbers of Foreign Visitors. Available online: http://www.ferdamalastofa.is/en/ recearch-and-statistics/numbers-of-foreign-visitors (accessed on 23 August 2016).

48. International Organization for Standardization (ISO). International Standard 14044: Environmental Management_Life Cycle Assessment: Requirements and Guidelines; ISO: Geneva, Switzerland, 2006.

49. Owens, J.W. Life cycle assessment-Constraints on moving from Inventory to Impact assessment. J. Ind. Ecol. 1997, 1, 37-49. [CrossRef]

50. Klöpffer, W. Life Cycle Assessment: From the Beginning to the Current State. Environ. Sci. Pollut. Res. 1997, 4, 223-228. [CrossRef] [PubMed]

51. Crawford, R.H. Life Cycle Assessment in the Built Environment; Spon Press: London, UK, 2011.

52. Suh, S.; Lenzen, M.; Treloar, G.; Hondo, H.; Horvath, A.; Huppens, G.; Jolliet, O.; Klann, U.; Krewitt, W.; Moriguchi, Y.; et al. System boundary selection in life-cycle inventories using hybrid approaches. Environ. Sci. Technol. 2004, 38, 657-664. [CrossRef] [PubMed]

53. Joshi, S. Product environmental life-cycle assessment using input-output techniques. J. Ind. Ecol. 1999, 3, 95-120. [CrossRef]

54. Hendrickson, C.; Horvath, A.; Joshi, S.; Lave, L. Economic Input-Output Models for Environmental Life-Cycle Assessment. Environ. Sci. Technol. 1998, 32, 184-191. [CrossRef]

55. Kitzes, J. An Introduction to Environmentally-Extended Input-Output Analysis. Resources 2013, 2, 489-503. [CrossRef]

56. Miller, R.; Blair, P. Input-Output Analysis: Foundations and Extensions, 2nd ed.; Cambridge University Press: New York, NY, USA, 2009.

57. Ten Raa, T. The Economics of Input-Output Analysis; Cambridge University Press: New York, NY, USA, 2006. 
58. Cicas, G.; Hendrickson, C.T.; Horvath, A.; Matthews, H.C. A Regional Version of a US Economic Input-Output Life Cycle Assessment Model. Int. J. Life Cycle Assess. 2007, 12, 365-372. [CrossRef]

59. The United Nations World Tourism Organization (UNWTO). Understanding Tourism: Basic Glossary I World Tourism Organization UNWTO. Available online: http://media.unwto.org/en/content/ understanding-tourism-basic-glossary (accessed on 20 October 2015).

60. Icelandic Tourist Board. International Visitors in Iceland, Winter 2013-2014. Available online: http:/ / www.ferdamalastofa.is/static/files/ferdamalastofa/kannanir/2014-10-03_ferdamalastofa_ erlendirferdamenn_maskinuskyrsla.pdf (accessed on 19 December 2015).

61. Icelandic Tourist Board. International Visitors in Iceland, Summer 2014. Available online: http:/ / www.ferdamalastofa.is/static/files/ferdamalastofa/Frettamyndir/2014/desember/2014-1217_ferdamalastofa_erlendirferdamenn_an_vaka_maskinuskyrsla_enska.pdf (accessed on 19 December 2015).

62. Statistics Iceland. Inbound Tourism Expenditure in Iceland by Consumption Products and Classes of Visitors, 2009-2013. Available online: http:/ /px.hagstofa.is/pxen/pxweb/en/Atvinnuvegir/Atvinnuvegir_ _ferdathjonusta_ferdaidnadur_ferdaidnadur/SAM08000.px (accessed on 21 October 2015).

63. Statistics Iceland. Passengers through Keflavik Airport by Citizenship and Month 2002-2015. Available online: http:/ / px.hagstofa.is/pxen/pxweb/en/Atvinnuvegir/Atvinnuvegir_ferdathjonusta_farthegar/ SAM02001.px (accessed on 21 January 2016).

64. DEFRA. Department for Environment Food and Rural Affairs. Guidance on How to Measure and Report Your Greenhouse Gas Emissions. Available online: https://www.gov.uk/government/publications/ guidance-on-how-to-measure-and-report-your-greenhouse-gas-emissions (accessed on 21 October 2015).

65. Icelandic Tourism Research Centre. Tourism Data Collection-Analysis at the Sub-National Level in Iceland. Akureyri. Available online: http://www.rmf.is/static/research/files/tourism-data-collection_profork.pdf (accessed on 21 October 2015).

66. Centre for Retail Studies (CRS). Mánaðarleg Kortavelta Erlendra Ferðamanna eftir Útgjaldaliðum. Available online: http://www.rsv.is/pages/kortavelta-ferdamanna/erlend-kort-utgjaldalidir/ (accessed on 21 October 2015).

67. Lewis, T. A Life Cycle Assessment of the Passenger Air Transport System Using Three Flight Scenarios. Master's Thesis, Norwegian University of Science and Technology, Trondheim, Norway, 2013.

68. Centre for Aviation, CAPA. World Aviation Yearbook 2013; Elizabeth Pinczewski, B.S., Ed.; CAPA: Sydney Australia, 2013.

69. Morrison, M.; Fafard, A. Making up the numbers. In World Airliner Census 2014; Flight International: London, UK, 2014; p. 22.

70. Morrison, M.; Fafard, A. Making it count. In World Airliner Census 2015; Flight International: London, UK, 2014; p. 21.

71. Carnegie Mellon University Green Design Institute. Economic Input-Output Life Cycle Assessment (EIO-LCA), US 1997 Industry Benchmark Model. Available online: http:/ /www.eiolca.net (accessed on 17 September 2015).

72. Heinonen, J.; Junnila, S. Case Study on the Carbon Consumption of Two Metropolitan Cities. Int. J. Life Cycle Assess. 2011, 16, 569-579. [CrossRef]

73. Heinonen, J.; Junnila, S. Implications of urban structure on carbon consumption in metropolitan areas. Environ. Res. Lett. 2011, 6, 014018. [CrossRef]

74. U.S. Bureau of Labor Statistics. Consumer Price Index. Available online: http://www.bls.gov/cpi/ (accessed on 20 November 2015).

75. Karlsdóttir, M.; Pálson, Ó.; Pálson, H.; Maya-Drysdale, L. Life cycle inventory of a flash geothermal combined heat and power plant located in Iceland. Int. J. Life Cycle Assess. 2015, 20, 503-519. [CrossRef]

76. Chester, M.; Horvath, A. Environmental assessment of passenger transportation should include infrastructure and supply chains. Environ. Res. Lett. 2009, 4, 024008. [CrossRef]

77. Statistics Iceland. Retail Prices. Available online: http://www.statice.is/statistics/economy/prices/retailprices / (accessed on 20 October 2015).

78. Shafiei, E.; Asgeirsson, E.I.; Davidsdottir, B.; Leaver, J.; Stefansson, H. Potential impact of transition to a low-carbon transport system in Iceland. Energy Policy 2014, 69, 127-142. [CrossRef] 
79. U.S. Energy Information Administration. Voluntary Reporting of Greenhouse Gases Program-Fuel Emission Coefficients. 2011. Available online: http://www.eia.gov/oiaf/1605/coefficients.html\#tbl2 (accessed on 21 October 2015).

80. Gössling, S.; Peeters, P.; Ceron, J.P.; Dubois, G.; Patterson, T.; Richardson, R.B. The Eco-efficiency of Tourism. Ecol. Econ. 2005, 54, 417-434. [CrossRef]

81. Dodman, D. Blaming cities for climate change? An analysis of urban greenhouse gas emissions inventories. Environ. Urban. 2009, 21, 185-201. [CrossRef]

82. Ottelin, J.; Heinonen, J.; Junnila, S. Greenhouse gas emissions from flying can offset the gain from reduced driving in dense urban areas. J. Transp. Geogr. 2014, 41, 1-9. [CrossRef]

83. Lee, D.S.; Pitari, G.; Grewe, V.; Gierens, K.; Penner, J.E.; Petzold, A.; Prather, M.J.; Schumann, U.; Bais, A.; Berntsen, T.; et al. Transport impacts on atmosphere and climate: Aviation. Atmos. Environ. 2010, 44, 4678-4734. [CrossRef]

84. Gössling, S. Sustainable Tourism Development in Developing Countries: Some Aspects of Energy Use. J. Sustain. Tour. 2000, 8, 410-425. [CrossRef]

85. Ala-Mantila, S.; Ottelin, J.; Heinonen, J.; Junnila, S. To each their own? The greenhouse gas impacts of intra-household sharing in different urban zones. J. Clean. Product. 2016. [CrossRef]

(C) 2016 by the authors; licensee MDPI, Basel, Switzerland. This article is an open access article distributed under the terms and conditions of the Creative Commons Attribution (CC-BY) license (http://creativecommons.org/licenses/by/4.0/). 